\title{
Obraz první Československé republiky při projednávání Ústavy $\check{C}^{1}$
}

\section{Image of the first Czechoslovak Republic in the debate about the Czech Constitution}

\author{
KLÁRA MARKOVÁ ${ }^{2}$
}

\begin{abstract}
This paper focuses on the image of the political system of the first Czechoslovak Republic in the political discourse connected with the preparation of the Czech Constitution in 1992. It works mainly with records of parliamentary debates between July and December 1992 and considers three types of actors: members of committees working on the constitution, constitutional lanyers and political figures with a significant informal influence, such as Václav Havel. The author asks three interrelated research questions: How was the first Czechoslovak Republic portrayed in the debates on the Czech Constitution? In what context of the discussions and argumentations did the First republic reappear? And what role did the image of the Czechoslovak Republic play in the debates? As I argue, the system of the first Czechoslovak. Republic was presented almost always positively, framed by concepts of tradition, democracy, sovereignty, and stability. Conversely, the Senate was portrayed more negatively, as a symbol of inefficiency, futility and expensiveness. The political system of the First Republic and the Constitution of 1920 represented an issue that could not be ignored and had to emerge through discourse. Some speakers did not always portray it properly and rarely spoke about the problematic aspects of the functioning of the political system of the First Republic. However, it was always alluded to as a symbol whose meaning was often more important than its actual content, as it could confirm the legitimacy of power relationships and express identification with a given political line. The fact that the actors chose only certain images of the First Republic, mostly the positive ones, illustrates that they sought to use the power of the symbol of the First Republic.
\end{abstract}

Keywords: Constitution of the Czech Republic; First Czechoslovak Republic; Constitution 1920; Political System; Constitution Making

\footnotetext{
1 Text vznikl v rámci projektu Specifického vysokoškolského výzkumu Promèny a duisledkey politických institucí č. 260 230/2015, na IPS FSV UK.

${ }^{2}$ Interní doktorandka, Institut politologických studií, Fakulta sociálních věd, Univerzita Karlova v Praze, U Kříže 8, 158 00, Praha 5 - Jinonice / Institute of Political Studies, Faculty of Social Sciences, Charles University in Prague, Czech Republic. E-mail: klara.markova@fsv.cuni.cz.
} 


\section{1. Úvod}

V literatuře zabývající se vznikem ústavních, resp. politických a volebních, systémů je česká ústava často uváděna jako př́klad působení silné historické tradice na podobu nového demokratického systému, jmenovitě tradice první republiky (např. Elster 1995; Elster, Offe, Preuss et al. 1998). ${ }^{3}$ Samotná česká ústava rovněž na tradici české a československé státnosti výslovně odkazuje, a to prímo v preambuli: „My, občané České republiky v Čechách, na Moravě a ve Slezsku, v čase obnovy samostatného českého státu, věrni všem dobrým tradicím dávné státnosti zemí Koruny české i státnosti československé“. 4

Předmětem tohoto článku je obraz politického systému první Československé republiky, resp. její ústavy, v politickém diskurzu při projednávání Ústavy České republiky. $V$ článku si kladu tři základní výzkumné otázky: za prvé, jaký obraz první republiky byl v debatách o ústavě vytvářen? Za druhé, v jakém kontextu se první republika v diskuzích a argumentacích vyskytovala? A konečně, jakou roli tento obraz v diskurzu hrál?

Cílem textu je ukázat, jak Ústavní listina Československé republiky z roku 1920 (dále též „Ústava 1920“) dodávala legitimitu nové české ústavě. Tato práce vychází z předpokladu, že pro úspěch a trvání ústavy, její přijetí politickou reprezentací i veřejností je důležitá legitimita. Právě spojení nové ústavy s předešlou respektovanou demokratickou tradicí nebo úspěšným zahraničním vzorem může pomoci legitimitu vybudovat (Offe 1996: 214). $\mathrm{Na}$ základě historické tradice nebo zahraniční zkušenosti mohou být také nazírány některé ústavní možnosti jako legitimní, jiné naopak jako nelegitimní (Renwick 2010: 45; Charvát 2013: 45).

Ačkoliv prvorepublikovou inspiraci zmiňují mnozí odborníci, zejména z oblasti ústavního práva (např. Filip 2002; Jirásková 2010; Mlsna 2010; Kopecký 2001), a někteři se snaží obě ústavy srovnávat (Gerloch 1999; Mlsna 2010) hlubší a systematická analýza role inspirace prvorepublikovým politickým systémem v diskuzích o ústavě chybí. Přitom vliv historické tradice v tranzitním období je dle teoretické literatury jedním ze základních způsobů formování ústav (Elster 1995; Elster, Offe, Preuss et al. 1998; Renwick 2000).

Je proto důležité pochopit, jak byl systém první československé republiky zobrazován aktéry podílejícími se na přijetí Ústavy ČR. Ač byla ústava vytvořena před skoro 25 lety, je dokumentem, který ovlivňuje náš život dodnes, protože

\footnotetext{
${ }^{3} \mathrm{~K}$ historické tradici se po prrechodu $\mathrm{k}$ demokracii prrihlásily také pobaltské státy, a to prímo tak, že obnovily platnost svých předválečných ústav, aby tak symbolicky demonstrovaly kontinuitu své státnosti, která byla přerušena nejprve připojením zemí k SSSR, pak obsazením Německem a následně opět připojením $\mathrm{k}$ SSSR. V prrípadě Litvy a Estonska se jednalo o přechodný stav, v Lotyšsku ovšem platí v novelizované podobě Ústava z roku 1922 dodnes (Suchánek, Jirásková et al. 2009: 24).

${ }^{4}$ Ústava České republiky ze 16. prosince 1992, ústavní zákon č. 1/1993 Sb.
} 
vymezuje „bitevní pole“ politického života a je základním pilírem, kterým stát komunikuje se svými občany. Ústava je také stále politickým tématem; dodnes se vedou debaty o jejích možných změnách, at' již v souvislosti s pravomocemi hlavy státu nebo o významu Senátu. Je proto důležité pochopit, jaké vlivy se do tvorby a výsledné podoby naší ústavy promítly, resp. zda a jakou roli hrála inspirace první republikou.

Následující text nejprve představuje teoretická východiska, dále ukazuje, jaká data byla analyzována, stručně vysvětluje použitou metodu a její epistemologické základy a předkládá krátký přehled literatury zabývající se tímto tématem. V další části popisuje kontext vzniku Ústavy ČR v druhé polovině roku 1992 a pokouší se také stručně nastínit postoje a zájmy politických stran, které se do tvorby ústavy promítaly. Posléze přechází k samotné analýze dokumentů. Nejprve se zabývám tím, jaké způsoby argumentace prvorepublikovým systémem, resp. Ústavou 1920, využívali aktérí ve svých promluvách, tedy jak k první republice odkazovali nebo se vůči ní vymezovali. Dále navazuje analýza konceptů, které byly spojovány s prvorepublikovým systémem, resp. její ústavou jako celkem i napříć jejími jednotlivými instituty. Jedná se tedy o takové asociace, které se prolínaly diskuzemi o nové ústavě a odkazovaly $\mathrm{k}$ první republice jako celku nebo zároveň i k jejím institucím. $\mathrm{V}$ další části se věnuji hlavním tématům, která se v diskurzu o nové ústavě vztahovala $\mathrm{k}$ první republice, zejména těm, která dostala $\mathrm{v}$ diskuzích a dokumentech největší prostor (tj. otázka Senátu a Stálého výboru parlamentu). $\mathrm{K}$ těmto dvěma tématům hledám asociace, která se $\mathrm{k}$ nim vážou.

\section{Teoretická východiska}

Článek vychází z teze, že systém první československé republiky byl jako symbol demokratické tradice využit pro zajištění legitimity nové české ústavy. Obecně platí, že ve snaze o vybudování podpory pro legitimitu nové ústavy a jejích institucí se aktéři často obracejí také $\mathrm{k}$ zahraničním vzorům. V případě diskuzí o Ústavě České republiky však nad zahraničními zkušenostmi silně převažovaly odkazy na první republiku. Zmínky o první republice nebo Ústavě 1920 se $\mathrm{v}$ analyzovaných dokumentech vyskytly $87 \mathrm{krát}$. Oproti tomu odkazy na zahraniční ústavy nebo jejich instituce byly nalezeny na 34 místech a 14krát aktéŕi v diskuzích odkazovali obecně na demokratické země/ústavy. Zmínky o federální, popř́padě komunistické ústavě byly velmi vzácné, nalezeny byly pouze $\mathrm{v} 6$ prrípadech. Můžeme proto říci, že odkazy na prvorepublikové zř́izení $\mathrm{v}$ diskuzích silně dominovaly.

Legitimitu politických institucí chápu v souladu s její moderní definicí zdůrazňující víru, důvěru nebo přesvědčení. Mattei Dogan uvádí, že instituce jsou legitimní, pokud je lidé považují za vhodné a morálně správné (Dogan 1992: 116). Pokud se podíváme, jak legitimitu politických institucí definují uznávaní političtí teoretikové, nalezneme u Lipseta, že legitimita je kapacita systému vybudovat 
a udržet důvěru lidí v to, že existující politické instituce jsou ty nejvhodnější pro danou společnost (Lipset 1959: 77). Podobně podle Linze je legitimita politického systému důvěra občanů $\mathrm{v}$ to, že i preses určité nedostatky a selhání jsou dané politické instituce lepší než jakékoliv jiné (Linz 1988: 65). S legitimitou ústavy jsou samozrejmě spjaty také otázky, jak a kým byla ústava schválena, jakým zpưsobem byl sestaven ústavodárný sněm, jaká $\mathrm{v}$ něm platila pravidla a nakolik ovlivnily zájmy jednotlivců, skupin a institucí konečný výsledek (Jirásková 1999: 198); jak ovšem upozorňuje Richard H. Fallon (2005: 1787), důležitější než proces tvorby a ratifikace ústavy je právě její společenské přijetí.

Český stát buduje svoji legitimitu na první Československé republice, která je široce pozitivně přijímaná jak mezi politiky, tak běžnými občany. Česká demokratická tradice je vyzdvihovaná jako důležitá součást politické kultury. Češi považují za své národní tradice právě tradici demokracie, kulturnosti a vzdělanosti (Holý 2010: 20). Můžeme to doložit tím, že čeští i zahraniční analytici často zdůrazňují, že Československo bylo $\mathrm{v}$ meziválečném období jedinou demokratickou zemí ve střední Evropě. Podle Ladislava Holého je třeba zkoumat, jak je tradice reprodukována $\mathrm{v}$ sociální praxi a čí zájmy vyjadřuje a prosazuje, protože ačkoliv se na tradici zdánlivě odvoláváme, abychom dali význam minulosti, vždy ji připomínáme z důvodu bud’ aktuálních, nebo budoucích cílů. Tradice je tudíž přpomínána, aby legitimizovala nebo nahradila současný status quo a aby mobilizovala občany (tamtéž: 139).

Vycházím z předpokladu, že státy posilují svoji symbolickou moc tím, že odkazují na svoji minulost, která je chápána jako „slavná“, „velká“ či „dobrá““. První republika funguje zároveň také jako symbol. Holý (tamtéž: 10-11) připomíná, že lidé dávají prostřednictvím symbolů smysl politickým procesům. Symboly jsou využívány $\mathrm{k}$ tomu, aby působily na emoce a nadchly pro politický program, potvrzovaly legitimitu mocenských vztahů a vyjadřovaly identifikaci s danou politickou linií. Právě symboly, mýty a tradice umožňují identifikaci lidí jako př́slušníků národa a vytváření národního vědomí.

Také historička Eva Broklová vidí meziválečnou československou demokracii jako jednu ze stabilních součástí fungujícího systému kolektivních symbolů, a dokonce $\mathrm{i}$ jednu $\mathrm{z}$ trvalých konstitutivních hodnot české národní identity a státnosti. Svoje tvrzení dokládá na výzkumech veřejného mínění: Např́klad z výzkumu z roku 1993 vyplynulo, že svátek 28. řijna je pro 86 \% obyvatel svátkem národa a nemá alternativu v jiném státním svátku. Prezident Masaryk se stal opakovaně jedním z nejčastějších vzorů českých dějin (Broklová 1999: 69-70). Dle Radovana Suchánka jsou státní svátky ve skutečnosti také jedním ze státních symbolů a stát jimi demonstruje vlastní existenci vůči svým občanům i vůči mezinárodnímu společenství. Státní svátky tak poukazují ke kořenům legitimity státu. Všechny současné státní svátky a významné dny vyjadřují zdroje národní totožnosti a demokratickou hodnotovou orientaci státu a zároveň se jimi přhlašujeme k ideji společné československé státnosti (Suchánek 1999: 114). Pro 
každý národ mají totiž určité historické události zvláštní symbolický význam a jejich výročí jsou oslavována jako svátky. Důležité je to, že významy vkládané do těchto událostí slouží jako záštita současného politického systému (Holý 2010: 51). Symbolickou sílu první republiky a její demokratické tradice můžeme vedle významu státního svátku 28. ř́ina po přechodu $\mathrm{k}$ demokracii doložit také např́klad tím, že se protirežimní demonstrace konaly na výročí důležitých událostí naší nedávné historie (mezi jinými i 28. října), a po revoluci byly vydávány knihy o první republice. ${ }^{5}$ Znovu vydány byly v roce 1991 nakladatelstvím Lidové noviny také svazky Ferdinanda Peroutky Budování státu. Je proto pochopitelné, že i tvůrci Ústavy ČR využili symbolu demokratické tradice první republiky k zajištění legitimity ústavy.

\section{Data a metodologie}

Základním zdrojem dat jsou záznamy z parlamentních jednání z období června až prosince 1992 (tj. období př́pravy Ústavy ČR). Pro účely tohoto textu budu za aktéry chápat politiky s reálnou mocí ovlivnit podobu ústavního systému, tedy zejména členy obou komisí pro prrípravu ústavy, dále ústavní experty a politické osobnosti s velkým neformálním vlivem, jako např́klad Václav Havel. Ve studii se soustředím na analýzu debat o ústavě v komisích a na plénu České Národní rady, protože to jsou místa, kde se ústava připravovala a schvalovala. Širší společenskou debatu v médiích jsem do analýzy nezačlenila zejména proto, že v prŕpadě tvorby české ústavy dominovaly politické elity a občané prostor pro zapojení nedostali. Roli sice při její př́pravě sehráli i experti - právníci, ale často nešlo o právníky ústavní a velká většina $\mathrm{z}$ nich byla $\mathrm{v}$ té době zároveň politiky nebo byla na politické strany nějak napojena (mj. Dušan Hendrych, Pavel Zářecký, Miroslav Sylla, Cyril Svoboda či Vojtěch Cepl). Ústavní právníci Pavel Peška, Vladimír Klokočka a Pavel Holländer se podíleli až na závěrečné oponentuře ústavy (Němeček 2010: 96).

Mnou zvolené zdroje však s sebou nesou několik problémů, se kterými jsem se musela vypořádat. Např́lklad činnost klíčové vládní komise není dostatečně zdokumentována. Archiv Úřadu vlády ČR dokonce k činnosti vládní komise nemá žádné primární zdroje. Zachovaly se pouze jednotlivé výstupy v podobě úvodních směrnic, zásad, ideového nástinu a návrhu ústavy, zásad ústavy, stanoviska Legislativní rady vlády a vládního návrhu ústavy. Nemáme ovšem k dispozici žádné záznamy z projednávání, kde by bylo možné sledovat probíhající debatu členů komise. Pokud jde o komisi předsednictva ČNR, rovněž není možné pracovat s úplnými záznamy o její činnosti, protože těsnopisný záznam začal být pořizován až ve druhé polovině srpna 1992, kdy již bylo o zásadách nové ústavy rozhodnuto. Stenozáznamy z jednání Komise ČNR a další dokumenty této

${ }^{5}$ Např́klad kniha Čskoslovenská demokracie. Politický systém ĆSR 1918-1938 české historičky Evy Broklové (Broklová 1992). 
Komise (usnesení, zápisy z jednání, atd.) byly proto spolu se stenozáznamy z 10. schůze ČNR z 16. a 17. prosince 1992, kde byla projednána Ústava ČR, stěžejním zdrojem pro analýzu. Do analýzy jsem zahrnula také text Václava Havla, ve kterém se vyjadřoval $\mathrm{k}$ uspořádání státu a který byl určen vládní komisi.

Pokud jde o metodologii, v článku pracuji a diskurzivní analýzou textu, která odmítá realistickou představu jazyka jako neutrálního prostředku k popsání reality a pro kterou proto není důležité, jestli je text pravdivý, přesný, zda ukazuje realitu a podobně. Místo toho zkoumá, jak lidé skrz text konstruují smysl a význam objektů v sociálním světě a jak je jazyk užíván k prezentování odlišných obrazů reality (Beneš 2008: 93; Tonkiss 2004: 248-249). Diskurz je charakterizován také způsobem, jakým kombinuje různé koncepty a kterým konceptům je př́suzována hlavní role (Ifversen 2003: 65). Pro lidské vnímání světa je totiž určující, jak věci pojmenováváme a do jakých souvislostí je svými koncepty dáváme (Holý 2010: 215). Koncepty a symboly nám slouží jako nástroje, skrze něž vykládáme a vytváŕíme svět, ve kterém žijeme. Pro interpretaci textu je však důležitý také kontext, ve kterém se diskurz odehrává. Kontext nemusí znamenat jen kde, kdy a mezi kým komunikace probíhala, ale mohou do něj být zahrnuty i další jemnější charakteristiky interakce, např́iklad o jaký typ aktivity se jednalo, jaká byla orientace účastníků atd. (Gill 2000: 176).

V článku zkoumám, jakou roli hrál politický systém první republiky a Ústava z roku 1920 v argumentaci aktérů připravujících a schvalujících českou ústavu v roce 1992 a v jakém kontextu se v textech první republika vyskytovala. Jinak řečeno, snažím se zachytit, jaký obsah, resp. obsahy dávali čeští politici konceptu politického systému první republiky, a hledat asociace, které se ke klíčovému pojmu první republiky $\mathrm{v}$ diskurzu vážou. Využívám pritom zejména analýzu slovníku, všímám si různých pojmenování a významu těchto pojmenování, významu slov, dále napríklad toho, jaká př́idavná jména byla využívána. Více ale z lingvistické úrovně do analýzy zahrnuto nebylo. Pozornost je tedy věnována zejména klíčovým slovům, frázím nebo tématům a nalezení asociací, které jsou s nimi spojené. $\mathrm{V}$ analýze diskurzu se tedy nesoustředím na jeho strukturu, ale naopak na jeho obsah. Domnívám se, že právě zvolený úhel pohledu mi umožňuje přesněji nahlédnout do procesu tvorby Ústavy ČR a prostřednictvím pečlivého zkoumání primárních i sekundárních zdrojů doplnit existující literaturu o procesu přípravy základního právního dokumentu České republiky. Vycházím totiž z prededpokladu, že koncepty, symboly a pojmenování věcí jsou v politické diskuzi používány jako určité nástroje a zbraně. Jsou použivány různým způsobem, aby splnily cíle politických aktérů, kteří je používají (Syrämäki 2013). Jak píše Fran Tonkiss, způsob, kterým používáme jazyk, je zřídkakdy nevinný, a diskurzivní analýza může pomoct odhalit, jak jsou texty a promluvy uspořádány, aby vytvářely konkrétní význam a účinek (Tonkiss 2004: 247). 


\section{Odkazy na první republiku v sekundární literatuře}

Zmínky o tradici první republiky nalezneme $\mathrm{v}$ mnohých komentárích $\mathrm{k}$ ústavě i v další sekundární literatuře. Důležitý je zejména komentář sestavený samotnými autory ústavy z vládní komise Dušanem Hendrychem, Cyrilem Svobodou a dalšími (Hendrych et al. 1997). Na několika místech je inspirace Ústavou 1920 zmíněna explicitně, nebo je naopak uvedeno, kde byla oproti jejímu textu provedena nějaká změna, nap̌r. „Tímto ustanovením se navazuje na tradici první republiky. Podle Ústavní listiny Československé republiky nikdo nemohl být více než dvakrát po sobě zvolen [prezidentem]“ (tamtéž: 87), „Koncepce úpravy imunity je inspirována Ústavou z r. 1920 (tamtéž: 39), „Ve srovnání s Ústavou z r. 1920 je prezidentova pravomoc rozpouštět Poslaneckou sněmovnu značně omezena“" (tamtéž: 55-56).

Tvưrci české ústavy však zmiňují v komentáři $\mathrm{k}$ ústavě kromě inspirace první republikou i další historické a zahraniční př́klady: „Byla vzata $v$ úvahu tradice první republiky a svým způsobem i tradice Federálního shromáždění. Rovněž bylo přhlédnuto ke zkušenostem $\mathrm{s}$ dvoukomorovým systémem $\mathrm{v}$ současných demokratických zemích" (tamtéž: 21).

Srovnání obou ústav ústavním právníkem Aleše Gerlochem (1999) rovněž vychází ze skutečnosti, že si tvůrci české ústavy dali v roce 1992 Ústavu 1920 za svůj vzor. Kontinuita se podle Gerlocha projevila zejména ve struktuře ústavního textu a v obnovení některých ústavních orgánů a jejich kompetencí - jedná se o parlamentarismus, triádu mocí (včetně vnitřní dělby uvnitř těchto mocî) a volební systém poměrného zastoupení. $K$ určitým posunům pak dle něj došlo u ústavního soudnictví, územní samosprávy a, což je podstatné s ohledem na zaměření tohoto článku, také $\mathrm{v}$ otázkách oslabení prezidenta a zejména obnovení Senátu, pro který však byla zvolena oproti Ústavě 1920 většinová volba s cyklickou dvouletou obměnou třetiny senátorů, plus byly pravomoci Senátu omezeny ve prospěch Poslanecké sněmovny (blíže viz Gerloch 1999:167-179).

Např́klad dle Jindřišky Syllové (2003), která se tvorby ústavy také zúčastnila, bylo celkem bez pochybností, že Česká republika bude parlamentarismem s vládou odpovědnou zákonodárnému sboru. Ústava 1920 byla podle ní pro politiky, kteří rozhodovali o nové ústavě, uznávaným dokumentem, což „výrazně zvyšovalo potenciál úspěšného přijetí nové ústavy v ČNR“ (Syllová 2003: 259). Dle Věry Jiráskové byly důvody pro inspiraci první republikou zejména emocionální a symbolické; převažovala potřeba přhlásit se k demokratickým tradicím české státnosti, spíše než přesvědčení, že je možné doslova přejmout ustanovení Ústavy 1920 (Jirásková 2010: 187; podobně Suchánek a Jirásková et al. 2009: 26). Jan Filip (2002: 296) zmiňuje, že „převážil názor, že koncepce Ústavy ČR by měla být v oblasti organizace státu návratem zpět $\mathrm{k}$ pevnému bodu“, kterým by měla být Ústavní listina z roku 1920. 


\section{Cesta k Ústavě ČR}

Na nové české ústavě se začalo pracovat v červnu 1992 v souvislosti s blížícím se rozdělením československé federace (ČSFR). Během dvou let od přechodu $\mathrm{k}$ demokracii se totiž v ČSFR príjetí nové federální ústavy ani ústav republikových nezdařilo.

Občanské fórum sice předložilo návrh nové ústavy již počátkem r. $1990,{ }^{6}$ ale tento návrh nebyl podobně jako návrh ústavy Václava Havla projednán, a žrejmě to ani nebyl cíl jeho tvůrců (Gerloch, Zoubek a Hřebejk 2013: 69). Nové demokratické elity se rozhodly pokračovat pod starou socialistickou ústavou, ze které byla odstraněna nejméně přijatelná ustanovení (Suk 2003: 271; Kopecký 2001: 25). Ke změně však došlo u volebního systému, když se nové elity rozhodly místo většinového volebního systému $\mathrm{v}$ jednomandátových obvodech, který byl využíván za komunistické éry, pro systém poměrného zastoupení, který byl využíván za první republiky. Jako hlavní zdůvodnění pro návrat k principu poměrné volby byly uváděny argumenty politického pluralismu, tedy aby i menšinové názory dostaly šanci na uplatnění (Cigánek 1992: 13-14).

První volební období svobodně zvolených parlamentů (Federálního shromáždění, České národní rady [ČNR] a Slovenské národní rady [SNR]) i mandát prezidenta byla podle dohody omezena na dva roky, během nichž mělo Federální shromáždění spolu s ČNR a SNR vytvořit novou ústavu. Důvodem zkráceného funkčního období bylo jak přesvědčení, že první svobodné volby budou spíše plebiscitem o změně režimu než volbou mezi politickými stranami na základě jejich programů, tak právě představa, že nově zvolené zákonodárné sbory budou plnit funkci ústavodárných sborů, které přijmou nové ústavy (Cigánek 1992: 13; Filip 1999: 86).

Práce na republikových ústavách byly započaty ihned na jaře 1990, práce na federální ústavě poté na podzim 1990; prípravovala ji komise vedená Mariánem Posluchem a Jiřím Boguszakem. Návrhy federální ani české ústavy však nebyly nikdy projednány, protože práce na ústavách byly přerušeny z důvodu otázek okolo další existence federace. Zúčastněné strany se dohodly, že jednání přenechají až vítězům vzešlým z voleb 1992 . Volby vyhrála v české části federace Občanská demokratická strana (ODS) a na Slovensku Hnutí za demokratické Slovensko (HZDS); tyto strany se však nebyly schopny dohodnout se na ničem jiném, než na rozdělení federace (Vodička a Cabada 2003: 304-305).

Desátého července 1992 byla ustavena vládní komise vedená premiérem Václavem Klausem (ODS) a místopředsedou vlády Janem Kalvodou (Občanská demokratická aliance, ODA), která se skládala výlučně z koaličních stran české vlády (ODS, ODA, Křest'anskodemokratické strany [KDS] a Křest'anské a demokratické unie - Československé strany lidové [KDU-ČSL]). Členy komise

${ }^{6}$ Dle Jana Filipa se tak mělo stát ještě v prosinci r. 1989 (Filip 2002: 296). 
byli akademičtí experti, vládní úředníci a poslanci Federálního shromáždění i ČNR. ${ }^{7}$ Svou komisi - Komisi předsednictva ČNR - vytvořila také Česká národní rada (viz ČNR 1992). Té předsedal Milan Uhde (ODS) a byli v ní poměrně zastoupeni reprezentanti všech parlamentních stran, včetně opozice. ${ }^{8}$

Zpočátku fungovaly obě komise souběžně, což se však poměrně brzy ukázalo jako problematické, a hlavní roli proto získala vládní komise. Jak vyplývá z materiálů $\mathrm{v}$ Archivu Poslanecké sněmovny, komise ČNR nejdříve sama diskutovala o principech, na kterých by měla nová ústava stát, a 16. července 1992 se usnesla na třinácti doporučeních $\mathrm{k}$ ústavě, které adresovala expertům vládní komise. Dále také komise diskutovala podobu jednotlivých institucí a zkusmo hlasovala o návrzích, aby měla vládní komise přehled, které úpravy mají naději na přijetí a které nikoliv. Od 18. záři 1992, kdy dostala od vlády první návrh ústavy, už pouze připomínkovala a doplňovala tento návrh. Návrh Ústavy ČR byl podán k nelibosti části členů komise ČNR jako vládní a nikoli poslanecký návrh (ČNR 1992b).

Komise měly $\mathrm{k}$ dispozici návrhy ústav z období federace. Obě komise si vyžádaly návrh první verze Ústavy ČR z poloviny r. 1991 zpracovaný komisí České národní rady (Filip 2002: 296). Vzhhledem k tématu tohoto článku je zajímavé, že tento návrh nevycházel kromě úpravy referenda z Ústavy 1920, ale inspiroval se modernějšími vzory ústav jiných federací, jako např́iklad německou a rakouskou ústavou nebo dále ústavami Řecka, Španělska a Portugalska (Filip 2002: 297). Podle vzpomínek Cyrila Svobody, kterého cituje novinář Tomáš Němeček, měli právníci vládní komise $\mathrm{k}$ dispozici také návrh federální ústavy (Němeček 2010: 82). Dle zápisu z jednání komise ČNR ze 14. července 1992 si tato komise vyžádala také Ústavní listinu z roku 1920 a materiály Národního shromáždění k př́pravě Ústavy 1920, návrh Ústavy Slovenské republiky a též publikaci Dokumenty k vývoji československého ústavního práva (Flegl 1989). Dále v Archivu Poslanecké sněmovny najdeme např. Evropskou chartu místní samosprávy a ústavy některých evropských států, a můžeme tedy předpokládat, že je měla komise také $\mathrm{k}$ dispozici. ${ }^{9}$

7 Dalšími členy vládní komise byli: Cyril Svoboda (sekretář komise), Filip Šedivý, Jiří Vlach, Vojtěch Cepl, Daniel Kroupa, Václav Benda, Václav Peřich, Jan Litomiský, Miloslav Výborný, Václav Novotný, Miroslav Sylla, Pavel Zářecký a Dušan Hendrych.

8 Členy byli: Marek Benda (KDS), Jiří Bílý (HSD-SMS), Pavel Hirš (LSU), Antonín Hrazdíra (LB), Ivana Janů (KDU-ČSL), Hana Marvanová (ODS), Ivan Mašek (ODA), Jaroslav Ortman (LB), Jiří Payne (ODS), Anna Röschová (ODS), Vítězslav Sochor (ČSSD) a Jan Vik (SPR-RSČ), náhradníci: Václav Grulich (ČSSD), Tomáš Ježek (ODA), František Kačenka (HSD-SMS), Jaromír Kalus (ODS), Jiř́i Karas (KDU-ČSL), Petr Koháček (ODS), Vladimír Koronthály (KDS), Jan Navrátil (LB), Jaroslav Novák (SPR-RSČ), Libor Novák (1962) (ODS), Vladimír Řezáč (LB) a Ondřej Zemina (ODS).

9 Archiv Poslanecké sněmovny, fond ČNR - VII. volební období (1992), NAD 8, krabice 33 (doplněk k inventárnímu číslu 280). 
S návrhy ústavy prrišly také další politické subjekty - Levý blok (LB), Československá strana sociálně demokratická (ČSSD) ${ }^{10}$ a Československá strana socialistická, ale i neparlamentní strany jako Občanské hnutí nebo Koruna česká. Oficiálně však nebyly $\mathrm{k}$ projednání připuštěny žádné $\mathrm{z}$ těchto návrhů a jejich text sloužil spíše jako podklad pro diskuzi (Filip 2003: 28; podobně Drahoš 2013: 20).

K ústavě se vyjadřoval i po své rezignaci na funkci prezidenta také Václav Havel, který 7. srpna 1992 uveřejnil text s názvem „Několik poznámek na téma české ústavy“ (Havel 1992), který adresoval členům vládní komise a v němž nastiňoval své představy o fungování nového státu. Pro zasazení následné analýzy do kontextu je třeba uvést, že Havel chtěl kandidovat na nového českého prezidenta a bylo také velmi pravděpodobné, že jím bude zvolen.

V situaci rozpadu Československa byla Ústava ČR přijata poslanci ČNR. Jak upozorňuje Petr Mlsna (2010: 21), ČNR byla využita jako ústavodárný sbor, aniž by byla pro tento účel konstituována, a také bylo dohodnuto, že se ČNR ve stávajícím složení přetransformuje na dolní komoru českého parlamentu, přičemž Federální shromáždění mělo být rozpuštěno. Zde je nutné upozornit, že federální poslanci byli stranickými špičkami, protože hlavní straničtí představitelé včetně předsedů stran kandidovali do Federálního shromáždění, a ne do České národní rady (Jičínský 2003: 74; Němeček 2010: 83). Jednou z otázek proto bylo, co s poslanci Federálního shromáždění, a jako možné řešení se nabízelo převedení poslanců FS do Prozatímního senátu.

Pro schválení nové ústavy byla potřeba třípětinová většina všech poslanců republikového parlamentu (120 poslanců). Ústava proto musela mít širší politickou podporu; kromě hlasů členů vládní koalice bylo pro její schválení potřeba alespoň 15 opozičních hlasů (Stein 2000: 307). Na plénu ČNR byla ústava projednávána 16. prosince 1992 a byla schválena bezpečnou většinou 172 poslanců ze 198 prítomných. Kromě vládních stran pro ústavu hlasovali i sociální demokraté, Hiršovi „,nezávislí liberálovéc"11 a většina Liberálně sociální unie (LSU) a Levého bloku. Proti hlasovali všichni republikáni, čtyři moravisté, jeden člen LSU a jeden poslanec Levého bloku, dohromady tedy šestnáct zákonodárců. Deset poslanců se zdrželo hlasování; jednalo se o zástupce moravistů, LSU a LB.

\section{a. Postoje aktérů}

Pro následnou analýzu dokumentů a záznamů z jednání spojených s př́pravou ústavy je třeba přblížit, jaké měly jednotlivé parlamentní strany, a zároveň též

\footnotetext{
${ }^{10}$ Návrh obsahoval naprŕíklad jednokomorový parlament a prrímou volbu prezidenta.

11 Pavel Hirš byl ve volbách v roce 1992 zvolen do ČNR za Československou stranu socialistickou (ČSS), respektive za koalici Liberálně sociální unie (LSU), jejíž součástí ČSS byla. V listopadu 1992 ale Hirš z poslaneckého klubu LSU odešel a spolu s několika dalšími poslanci založil Liberální klub.
} 
Václav Havel jako osoba s vysokým neformálním vlivem, postoje k podobě politických institucí, co chtěly a o co usilovaly. Vzhledem $\mathrm{k}$ tomu, že postoje aktérů byly často utvářeny po stranické linii a nemáme bohužel dostatek informací o preferencích a názorech jednotlivých politiků, budu se $\mathrm{v}$ následující části věnovat zejména stranickým postojům. Je však třeba připustit, že v některých otázkách byly strany dost rozdělené. $\mathrm{K}$ nejvíce diskutovaným tématům při tvorbě české ústavy, které se týkaly politického systému a zároveň obsahovaly odkazy na první republiku, patrílo postavení a volba prezidenta, postavení Poslanecké sněmovny a zř́zení druhé komory Parlamentu.

Co se týče postavení a volby prezidenta, Václav Havel propagoval silnější postavení hlavy státu a přál si prrímou volbu, kterou spojoval s vyšší legitimitou této funkce. Byla však pro něj přijatelná i volba oběma komorami parlamentu (Havel 1992: 10-13). Silnějšího prezidenta prosazovala jako jediná z parlamentních stran CSSD. Naopak pro prrímou volbu prezidenta byla kromě ČSSD i část vládní koalice, zejména ODA a KDU-ČSL. Koaliční strany, zejména ODS, prosazovaly naopak co nejslabšího prezidenta, protože předpokládaly, že jím bude opět zvolen Václav Havel (Kopeček 2010: 158; Kopecký 2001: 39; Stein 2000: 307). Vláda také prezidentovi nechtěla svěřit zákonodárnou iniciativu a zprvu mu nepřiznala ani suspenzívní veto běžných zákonů. Proti tomu se však hlasitě ozývali jak Havel, tak ČSSD, a vláda nakonec ustoupila (Kopecký 2001: 40; Stein 2000: 289, 295). Prezident dostal pravomoc rozpouštět Poslaneckou sněmovnu pouze ve vyjmenovaných situacích. Poslanecká sněmovna je tak vlastně proti vlastní vůli nerozpustitelná a stala se nejsilnějším orgánem politického systému. Vzhledem k tomu, že Česká národní rada byla institucí, která ústavu přijímala a ze které vznikla Poslanecká sněmovna, je to poměrně logické. Postavení Poslanecké sněmovny bylo posíleno také zákonodárnou iniciativou, která náleží i jednotlivým poslancům, a zejména velkoryse pojatou doživotní imunitou poslanců (Wintr 2013: 256, Němeček 2010: 93-94).

Dalším důležitým bodem diskuze týkajícím se Poslanecké sněmovny bylo kvorum pro príjetí ústavních zákonů. Vláda prosazovala pouze nadpoloviční většinu pro přijetí ústavních zákonů a mezinárodních smluv, namísto tř́pětinové většiny všech př́tomných poslanců a senátorů. Opozice i Havel proti této úpravě důrazně protestovali, protože by to znamenalo, že tehdejší vládní koalice, která disponovala absolutní většinou, by mohla sama měnit ústavu (Stein 2000: 287; Filip 2003: 31).

Velkým tématem také bylo, jestli zrídit Senát, a pokud ano, jak ho koncipovat. Hlavním přívržencem Senátu byla ODA, která argumentovala existencí druhé komory za první republiky i v jiných evropských státech a její funkcí ústavní pojistky. Významná část ODA prosazovala myšlenku dělby práce mezi komorami na soukromé a veřejné právo podle vzoru F. A. Hayeka (Hayek 1994). Stala se ale velkým odpůrcem zrrízení prozatímního Senátu, do něhož měli být podle určitého klíče přesunuti poslanci Federálního shromáždění. Pravděpodobným důvodem 
byla skutečnost, že ODA neměla ve FS žádné zastoupení (Kopecký 2001: 334; Kopeček 2010: 160). Názory na vytvoření Senátu se lišily jak uvnitř vládní koalice, tak i uvnitř jednotlivých stran. Proti Senátu byla ČSSD a Sdružení pro republiku Republikánská strana Československa (SPR-RSČ). Senát zprvu plně nepodporovala ani ODS, ale když zjistila, že proti Senátu jsou sociální demokraté a že by Senát mohl posloužit jako oslabení prezidenta, začala ho prosazovat. Dokud byla na stole varianta Senátu jako zástupce regionů, podporovaly ho Levý blok, ${ }^{12}$ Hnutí za samosprávnou demokracii - Společnost pro Moravu a Slezsko (HSD-SMS) a částečně též Liberálně sociální unie. Poté, co vláda tuto možnost odmítla, přestala tato uskupení Senát podporovat; Levý blok pak proti němu začal ostře vystupovat (Kysela 2004: 419-426; Stein 2000: 286). Václavu Havlovi přišel Senát zbytečný, nicméně varianta Senátu jako zástupce regionů pro něj byla príjatelná (Havel 1992: 6).

\section{První republika jako vzor?}

Odkazy na první republiku nalezneme už v dokumentech, které udávaly směřování ústavy. Řeč je např́klad o „Zásadách Ústavy České republiky zpracovaných [vládní komisí] dne 18. 7. 1992“, podle nichž měla být Ústava ČR „jednoduchá a navazovat na osvědčené tradice Ústavní listiny z r. 1920“ (ČNR 1992c). Tyto zásady vznikly na základě usnesení Komise předsednictva ČNR pro př́pravu Ústavy České republiky a byly adresované expertům vládní komise. Ze trrinácti základních tezí odkazovaly dvě prrímo na ústavu první republiky: 1. „V zájmu kontinuity československého a českého státu by měla nová ústava vycházet z těch principů, z nichž vycházela Ústavní listina Československé republiky z 29. 2. 1920, které se osvědčily“. 2. „Komise doporučuje při stanovení pravomocí prezidenta vycházet z postavení dle Ústavní listiny Československé republiky z 29. 2. 1920 a uvážit posílení funkce premiéra“. Mimo to $v$ jedné tezi komise doporučuje zachovat tradiční parlamentní systém (ČNR 1992d). Zde vidíme, že komise nechtěla přebírat prvorepublikovou ústavu jako celek, ale že si vytvářela prostor pro určitý odklon od ní.

Někteří členové Komise ČNR argumentovali pro přijetí institutů inspirovaných Ústavou 1920 tím způsobem, že připomínali, že se už v komisi přece drríve shodli, že budou vycházet $z$ prvorepublikové ústavy. Př́kladem mohou být slova Hany Marvanové (ODS) na podporu pravomocí Senátu: „Pokud se podíváte do Ústavy z roku 1920, jak to bylo formulováno v \42, a my jsme se rozhodli, že se k ní budeme vztahovat..." (ČNR 1992b). Ivan Mašek (ODA) žádal, aby se vycházelo z Ústavy 1920 a odbočovalo se od ní pouze $\mathrm{v}$ př́padech, kdy některý institut nefungoval dobře: „My jsme se dohodli, že budeme vycházet

12 Jako volební koalice Levý blok kandidovaly v roce 1992 Komunistická strana Čech a Moravy (KSČM), Strana demokratické levice a další menší levicová uskupení. 
z principů Ústavy 1920 a tak by se spíše mělo argumentovat v tom, které principy se neosvědčily, a ty je třeba měnit a nikoli obráceně“ (ČNR 1992b).

Podobně se Marek Benda (KDS) ptal ohledně pověrení vlády při její demisi nebo odvolání, „proč nebylo voleno řešení, které platilo už v první republice“ (tamtéž). Podobná prohlášení je možné nalézt nejenom u politiků z vládní koalice, ale i u opozičních poslanců jako jsou Pavel Hirš (LSU) ${ }^{13}$ a Jaroslav Ortman (LB). Poslanec LSU a člen Komise ČNR Pavel Hirš se např́ílad ptal, „Proč vláda neuvažovala s tímto Stálým výborem, jak ho měla první republika, protože jsme řekli, že budeme vycházet z Ústavy 1920 a tam se tento princip osvědčil..." (tamtéž). Jaroslav Ortman (LB) se vyjadřoval k Senátu na 10. schůzi ČNR otázkou, „proč se skutečně nenavázalo na tradici, která tady byla za první republiky, tzn. rovnocenné postavení komor“ (tamtéž), nebo v diskuzi v Komisi ČNR, kde prohlásil, že „Považuji rozhodnutí komise (vládnî) za ne zcela št'astné a odporující Ústavě 1920, nebot' staví Senát do zcela jiného světla a do jiné polohy“ (tamtéž). Tato vyjádření poslance Ortmana se však rozcházejí s kritikou prvorepublikového Senátu, kterou nalézáme ve zdůvodnění návrhu ústavy z dílny Levého bloku, kde byl Senát první republiky prezentován jako neúspěšný (viz níže) (ČNR 1992e). Také se musíme zamyslet nad otázkou, proč Ortman mluvil o rovnocenném postavení komor, když tomu tak za první republiky nebylo (ač je pravdou, že bylo mnohem rovnocennější než dnes). Bud' tedy autor výroku využíval argument první republiky pouze účelově, nebo nebyl dostatečně obeznámen s politickým systémem první republiky.

Ne vždy však byla Ústava z r. 1920 připomínána ve smyslu volání po jejím následování. V textech je možné nalézt otázku, zda určitá ustanovení z ústavy z r. 1920 přebírat nebo ne. Př́kladem může být Marek Benda (KDS): „Měli bychom se asi bavit o kvórech pro prijímání ústavních zákonů, obyčejných zákonů, o tom, jakým způsobem chceme vyř̌šit tuto věc, zda budeme prejejímat principy první republiky - třípětinová většina, absolutní většina atd.“ (ČNR 1992b). Benda však dále tvrdil, že jeho návrh z ústavy první republiky vychází (tamtéž). I on tedy využíval odkaz na první republiku k podpoře svého návrhu.

Ve studovaných textech je samožrejmě možné nalézt i odmítání některého institutu Ústavy 1920, zejména co se týče Senátu. Velmi explicitně odmítl prvorepublikový vzor člen Komise ČNR za ČSSD Vítězslav Sochor, který použil prŕmo spojení „,nechceme dodržovat“: „Nechceme dodržovat v této záležitosti Ústavu 1920 a jsme toho názoru, pokud bude Senát, aby doba jeho trvání byla shodná s parlamentem, čili 4 roky, aby byla odvolatelnost současně s parlamentem..." (tamtéž). Na tomto výroku je zajímavé, že poslanec Sochor

13 U Pavla Hirše je ale potřeba upozornit, že ačkoliv byl opozičním poslancem, členem Československé strany socialistické (ČSS), respektive koalice Liberálně sociální unie (LSU), často praktikoval politiku odlišnou od LSU a hlasoval s vládní koalicí. V listopadu 1992 odešel z poslaneckého klubu LSU a spolu s několika dalšími kolegy a bývalými členy SPR-RSČ ustavil Liberální klub. LSU proto nominovala do komise PČNR pro prrípravu ústavy jiného zástupce. 
říká, že odmítá Ústavu 1920, kde bylo volební období Senátu stanoveno na 8 let a Sněmovny na 6 let, nicméně systém první republiky se potýkal s problémy mimo jiné proto, že nebylo dodržováno osmileté volební období a místo toho bylo volební období obou komor ukončováno současně. Toho se chtěla nová česká ústava vyvarovat. Je také potřeba připomenout, že ČSSD se stavěla velmi silně proti zř́zzení Senátu, a je tedy otázkou, zda toto nebyl jen určitý manévr.

Častěji než explicitní odmítnutí nějakého institutu z Ústavy 1920 je možné nalézt vyjádření, v čem se bude navrhovaný institut od prvorepublikového vzoru lišit, jako např́klad ve vystoupení Marka Bendy (KDS): „Stálé výbory by neměly tu možnost zákonodárných opatření tak, jak to bylo za první republiky, pouze v situaci, kdy by byly vyhlášeny volby do Poslanecké sněmovny, pak by měly možnost zákonodárných opatření" (tamtéž). Není ale patrné, z jakého důvodu nemá být přebrána úprava z roku 1920 jako celek nebo proč by měla být změna př́nosná. Pro poslance Hirše (LSU) bylo zase důležité vysvětlit, proč se jeho návrh odklání od prvorepublikové ústavy: „My jsme řekli, že budeme vycházet z Ústavy 1920 a kdybychom přijali jiné principy, tak to musíme odůvodnit. Já jsem to odůvodnil tím, že se domnívám a jsem přesvědčen, že nadpoloviční většina je reprezentativni" (tamtéž).

V celkovém pohledu je tedy $\mathrm{v}$ daných dokumentech možné nalézt jak apely na přejímání prvorepublikové ústavy, tak odmítnutí jejího následování, př́padně vysvětlení, kde se aktéŕi ve svých návrzích od prvorepublikového vzoru odklánějí. Pro tento článek je ale podstatná samotná skutečnost, že aktéri měli potřebu prvorepublikovou ústavou argumentovat a nějakým způsobem, at' kladně nebo záporně, se k ní vztahovat.

\section{7. Ústava 1920: tradice, osvědčenost, demokracie}

Např́íc analyzovanými texty byla ústava první Československé republiky jako celek, ale i jednotlivé instituty tehdejšího politického systému, často spojována se slovy „tradice“ a „tradični“; nalézáme též spojení typu „osvědčená tradice“, „moudrá myšlenka první republiky“ a podobně. Nová ústava měla např́lklad navazovat na „osvědčené tradice Ústavní listiny r. 1920“ (ČNR 1992b). V odůvodnění návrhu Ústavy České republiky podaného poslanci Levého bloku se psalo, že se přejímají „osvědčená ustanovení Ústavní listiny č. 121/1920 Sb.“ (ČNR 1992e). Pavel Hirš (LSU) při jednání v Komisi ČNR k institutu Stálého výboru zakotveném v prvorepublikové ústavě prohládil, že se „tento princip osvědčil“" (ČNR 1992b). Jiř́ Payne (ODS) označil Stálý výbor za „velmi moudrou myšlenku první republiky“ (tamtéž). Jiří Šoler mluvil o vytvoření „silného, suverénního a demokratického Československa plně v duchu Masarykových tradic" (ČNR 1992f). Poslanec Payne dále označil existenci uvozovacího zákona jako „velmi pozitivní tradici Ústavy z roku 1920“ (ČNR 1992d). Parlamentní systém byl označován jako tradiční (tamtéž), v textech se objevuje také „tradiční 
8leté volební období“ do Senátu (ČNR 1992f) a požadavek „změnit počet senátorů v souladu s tradicí na 100“ (tamtéž). O úřednické vládě Václav Havel (1992: 14) napsal, že „Tato věc se za první republiky osvědčila“. Naopak Senát prezentoval Havel jako instituci, která u nás „nemá žádnou smysluplnou tradici“ (tamtéž: 5). Tradice se tedy objevila i ve smyslu něčeho chybějícího. Havel se snažil podpořit svůj názor, že by prezident neměl být odvolatelný parlamentem, tezí, že „Ústava 1920 to věděla“ (tamtéž: 12), čímž ji také zobrazoval jako moudrou a osvědčenou - a svoji pozici posílil tím, že ji zživotnil: „ona to věděla“. Oproti tomu místopředseda vlády a místopředseda vládní komise Jan Kalvoda (ODA) prvorepublikovou ústavu jako osvědčenou neprezentoval, když ve své odpovědi na dotazy členů Komise PČNR k poslanecké imunitě použil spojení „výjimečné řešení", které je však míněno negativně jako něco vybočujícího: „Pokud je mi známo, tak to byla jen Ústava z roku 1920, československá ústava, která znala doživotní imunitu a jinak to je řešení snad výjimečné“ (ČNR 1992b).

Dalšími pojmy, které byly $\mathrm{v}$ diskurzu politiků asociovány s politickým systémem první republiky jako s celkem nebo se prolínaly i se zobrazením jednotlivých institutů, byly demokracie, suverenita, humanismus, účinnost, stabilita, kontinuita a aktuálnost. Vládní komise v Zásadách Ústavy České republiky zpracovaných dne 18. 7. 1992 uvedla, že ústava by měla být jednoduchá a navazovat na tradice Ústavní listiny z roku 1920. „Tento základní záměr, totiž co největši efektivnost rozhodovacích procesů, nesmí ohrožovat druhou základní funkci ústavy, která spočívá $\mathrm{v}$ ochraně a zajištění demokratického politického systému“ (ČNR 1992c). Může to působit tak, že Ústava 1920 byla spojována s efektivitou a zároveň postavena proti demokracii, ale mohlo to být myšleno jinak. Dokument Komise ČNR vykresloval ústavu první republiky jako funkční a osvědčenou a vyzdvihoval potřebu kontinuity, kterou by mělo navázání na prvorepublikovou ústavu přinést (ČNR 1992d).

Petra Buzková (ČSSD), Stanislav Volák (ODS) i Jiř́ Šoler (SPR-RSČ) spojovali první republiku s pojmem demokracie, každý ale v jiném kontextu. Buzková spojovala demokracii s potřebou kompromisu ve smyslu státotvornosti a odpovědnosti. Připomínala kompromis ze strany prvorepublikové sociální demokracie ve spojitosti s prrijetím prvorepublikové ústavy, aby podpořila svoji žádost o kompromis ze strany vlády při přijímání současné ústavy, tedy aby vláda vyšla vstříc některým opozičním návrhům (ČNR 1992f). „Státotvornost“ samu o sobě akcentoval ve svém projevu na 10. schůzi ČNR také Vlastimil Vlček (ODS), který ji spojoval s některými výraznými osobnostmi české historie, zejména s Antonínem Švehlou a jeho podílem na vytvoření Ústavy 1920, a využil toho k žádosti o podporu předloženého vládního návrhu české ústavy (tamtéž).

Poslanec ODS Stanislav Volák spojoval fungování první republiky s demokracií a ekonomickou a politickou stabilitou a umocnil to kontrastem se sousedními autoritativními režimy ve 30. letech 20. století: „Po dobu své existence se [první republika] lišila nejen stálým kurzem, vyrovnaným rozpočtem 
a minimální inflací, ale především stabilitou svých demokratických institucí v době, kdy všude okolo vládl autoritativní režim“ (tamtéž).

Poslanec SPR-RSČ Jiř́ Šoler prezentoval ústavu první republiky jako symbol síly, suverenity a demokracie a stavěl ji proti nové ústavě, kterou odmítl právě z důvodu, že legalizovala rozpad Československa. Republikáni totiž vystupovali po celou dobu státoprávní krize proti rozdělení země a nikdo z nich novou českou ústavu nepodpořil. Při 10. schůzi ČNR, na které se o ústavě hlasovalo, Šoler řekl: „Cílem naší strany je vytvoření nového silného, suverénního a demokratického Československa plně v duchu demokratických tradic. Je nám př̀edložena ústava ducha přesně opačného. Dovršuje a legalizuje rozpad Československé republiky a navíc $\mathrm{v}$ ní nevidím ani dostatečné záruky státní suverenity a demokratického vývoje“ (tamtéž). S pojmem suverenity/svrchovanosti pracovala také Gerta Mazalová (HSD-SMS), která použila pro Československou republiku vzniklou roku 1918 př́zviska „svrchovaný a samostatný stát“, když citovala na 10. schůzi ČNR z Deklarace práv lidu Moravy a Slezska, aby podpořila požadavek na samosprávu těchto částí (tamtéž).

Václav Havel spojoval první republiku s pojmem humanismu a prezentoval ji jako součást „humanistické tradice“, „tradice pocitu širší spoluodpovědnosti za věci lidské“, „tradici určité duchovnosti“" v českém prostředí, kterou spojoval s významnými osobnostmi v českých dějinách, mezi něž řadil sv. Václava, Karla IV., Jiř́ho z Poděbrad, Komenského a Masaryka (Havel 1992: 2).

Prvorepubliková ústava byla také asociována s modernitou a aktuálností. Např́iklad Jiří Payne (ODS) označoval skutečnost, že v prvorepublikové ústavě bylo definováno, co je ústavní zákon, za ,„jeden z nejmodernějších prvkư“ (ČNR 1992b). To ale neodpovídalo skutečnosti a je proto otázkou, zda se z Payneovy strany jednalo o účelový tah, nebo - opět - Ústavu 1920 dostatečně neznal. Otázku aktuálnosti využil také Pavel Hirš (LSU), aby podpořil pravomoc prezidenta rozpustit Poslaneckou sněmovnu: „Mám před sebou Ústavu z r. 1920 \31. Řekli jsme, že z této ústavy budeme vycházet, pokud bude splňovat podmínky doby. V odstavci 1 se prímo hovoří, že prezident má právo rozpustit Sněmovnu. Ted' musíme říci, za jakých okolností. Souhlasím s kolegou Bendou, ale domnívám se, že by tam mělo být zakotveno, že ji nesmí rozpustit v době 6 měsíců před skončením volebního období“ (tamtéž). Hirš zde připomíná podmínku nerozpustitelnosti Sněmovny 6 měsíců před skončením volebního období, která byla ale v Ústavě 1920 myšlena jako volební období prezidenta a ne Sněmovny, což, jak se zdá, Hirš zaměnil. Zároveň Hirš neodmítl další možná omezení, která navrhoval např. poslanec Marek Benda, ale která Ústava 1920 neznala. Také Václav Havel řadil Ústavu 1920 mezi moderní ústavy, které definovaly, kdo je zdrojem moci ve státě. Na jiném místě však napsal, že „v ústavě z roku 1920, poplatné jinak plně dobovému pozitivistickému pojetí ústav jako pouhých organizačních řádů, je hned v základních ustanoveních řečeno, že v čele republiky stojí prezident..." (Havel 1992: 15). Přestože tedy byla podle Havla 
prvorepubliková ústava $\mathrm{v}$ některých ohledech zastaralá, obsahovala toto důležité ustanovení, které on navrhoval převzít.

\section{Hlavní témata diskuzí spojená s první republikou}

Ve vztahu k systému první republiky nalézáme $\mathrm{v}$ diskurzu následující témata: parlamentarismus, Senát, prezident, Stálý výbor parlamentu, proporční volební systém, samospráva Moravy a Slezska, referendum, úřednická vláda. Co se týče osobností, které byly zmiňovány jako významné pro fungování prvorepublikového politického systému, jednalo se o prezidenty Masaryka a Beneše, předsedu několika prvorepublikových vlád a předsedu agrárníků Švehlu a sociálně demokratického poslance a ministra Meissnera. Mimoto byly jako určité vzory vzpomínány i straší historické postavy od sv. Václava po K. H. Borovského. Švehla a Meissner byli zmiňováni v souvislosti s jejich zásluhou na vytvoření, resp. přijetí prvorepublikové ústavy. Ve vystoupeních poslanců, zejména při rozpravě v plénu ČNR, nalézáme kromě odkazů na text Ústavy 1920 i odkazy na další prvorepublikové dokumenty, jako byla Washingtonská deklarace z r. 1918 nebo různé záznamy z parlamentních jednání o prvorepublikové ústavě z února 1920. Tématy, která $\mathrm{v}$ diskuzích a dokumentech získala největší prostor a kterým se proto budu blíže věnovat, byly Senát a Stálý výbor parlamentu.

\section{a. Senát}

Senát byl asociován s pojmy neefektivnost, neužitečnost (zbytečnost), nákladnost a neaktuálnost. Zejména opozice a Václav Havel hodnotili Senát jako nevhodný. Levý blok v Odůvodnění svého návrhu české ústavy uvedl, že jejich ústava koncipuje ČNR jako jednokomorový zákonodárný sbor. „Senát, který existoval za první republiky, se neosvědčil (byl reminiscencí na panskou Sněmovnu, komplikoval přijímání zákonů, zatěžoval státní pokladnu bez společenské užitečnosti), proto se s ním v návrhu nepočítác (ČNR 1992e). Podobně hodnotila prvorepublikový Senát také poslankyně Gerta Mazalová (HSD-SMS). „Je notoricky známo, že se za první republiky neosvědčil. Byla to instituce velice drahá a pritom, jak všichni víme - také nefunkčni““ (ČNR 1992f). Senát nazvala „penziónem pro starší a dlouhodobě nemocné poslance“ (tamtéž). Její stranický kolega Jiří Bílý nastavení prvorepublikového Senátu hodnotil nejen jako nefunkční, ale také jako zastaralé: „Pokud bude Senát fungovat v té filozofii, jaká je vyjádřena $\mathrm{v}$ ústavě, mám pocit, že vrací ústavu o pár desítek let zpátky a dostáváme se $\mathrm{k}$ situaci už dávno překonané a vlastně i historií potvrzené, že Senát (....) byl za první republiky nefunkční“ (ČNR 1992b). Jedinou podobu Senátu, kterou byli ochotni moravisté podpořit, byl Senát vytvořený na základě regionálního zastoupení, který ale vláda zamítla. Podobně se k Senátu vyjádřil Václav Havel: „Po celou první republiku to bylo mrtvé a zbytečné těleso“ (Havel 1992: 5). Stejně tak byl pro něj odstrašující dvoukomorový parlament z doby 
federace, kterému vytýkal zdlouhavé přijímání zákonů. Také pro něj by byl jediný smysluplný Senát na regionální bázi, k čemuž dával př́iklady fungujících druhých komor v Německu a Rakousku (Havel 1992: 6-7). Havel označil prvorepublikový Senát jako „výměnek pro zasloužilé staré pány, resp. jejich odkladištěc (Havel 1992: 5). Poslanec ODA Ivan Mašek mluvil o prvorepublikovém Senátu jako o nefunkčním, ale dal ho do kontrastu s původním návrhem Senátu, který počítal s odlišným volebním systémem. Ve stenoprotokolu se dočteme:

„Jak zdánlivě drobné úpravy mohou institut Senátu poškodit, ukazuje př́klad první republiky. V průběhu politických jednání byl původní návrh nerozpustitelného Senátu s osmiletým volebním obdobím, v němž se vždy po 4. letech volila polovina senátorů, změněn na Senát rozpustitelný a volený najednou (...) To spolu s tím, že Senát byl volen poměrným způsobem, tedy stejně jako Poslanecká sněmovna, zavinilo i špatnou funkci a pověst Senátu po celé období první republiky“ (ČNR 1992f).

Mašek tímto způsobem obhajoval existující návrh, který se dle něj těchto chyb vystříhal. Za takovýchto podmínek by byl podle něj Senát nezbytností pro demokratické fungování, protože by působil jako prvek stability a kontroly moci. Zajímavé ale je, že o pár vět dále dává delší volební období Senátu za první republiky za prríklad a doplňuje ho dalšími zahraničními př́klady. Způsob naplňování prvorepublikového Senátu jako takové odmítá, ale délka volebního období mu slouží jako podpora jeho argumentu (tamtéž).

\section{b. Stálý výbor}

Stálý výbor parlamentu byl v diskurzu spojen s pojmy stability, funkčnosti a demokracie, ale naopak také nefunkčnosti. Pro Pavla Hirše (LSU) měl Stálý výbor, který podle Ústavy 1920 nastupoval do funkce v př́padě rozpuštění Poslanecké sněmovny, „významnou ústavní funkci“ (ČNR 1992b). Podle člena Komise ČNR za ODS Libora Nováka byl v prvorepublikové ústavě „poslední pojistkou ústavnosti“, ze které se „rozvine celý ústavní systém v př́padě, že došlo k jeho zhrouceni“" (tamtéž). Jiř́ Payne (ODS) mluvil ve spojitosti se Stálým výborem o řešení výjimečného stavu a překlenutí období, kdy je rozpuštěná Poslanecká sněmovna a Stálý výbor tak plní kontrolní funkci vůči vládě. Naproti tomu Marek Benda (KDS) hodnotil Stálý výbor jako nefunkční v souvislosti s tím, že byl tvořen poměrně. Problém viděl v tom, že ,pokud je parlament rozpuštěn, z nějakého důvodu byl prohlášen za neschopný činnosti, potom i ten Stálý výbor je velmi problematický zvláště za předpokladu principu poměrného zastoupení, protože parlament zréejmě nebyl schopen se na něčem dohodnout" (tamtéž). Jako řešení pro období, kdy je rozpuštěna Poslanecká sněmovna, navrhoval Benda Senát, který by převzal na nutné období základní funkce Poslanecké sněmovny. Je potřeba dodat, že když byl v komisi ČNR diskutován Stálý výbor po vzoru první 
republiky, byl také často spojován s v té době existující institucí předsednictva ČNR.

\section{Role zahraničních vzorů}

Jak už jsem naznačila výše, na podporu svých tvrzení politici používali kromě príkladu první republiky také zahraniční vzory, bud' jmenovitě konkrétní státy, nebo mluvili obecně o demokratických zemích. Odkazy na zahraniční vzory používali aktéŕi třemi způsoby. Zaprvé samostatně na podporu svých argumentů. Dále spolu s př́kladem první republiky, aby své argumenty navzájem podpořili a umocnili, resp. se snažili podpořit sílu faktu tvrzením, že daný institut v Ústavě z r. 1920 je ověřený i zahraničními zkušenostmi. A naposledy jako protiargument k nějakému institutu první republiky, který byl dle nich problematický. Druhý př́pad se týká např́ílad argumentace Václava Havla: „V Ústavě z r. 1920 referendum rovněž bylo, i když se žádné nekonalo. $Z$ principu by ale $\mathrm{v}$ ústavě jako ústavní institut zakotveno být mělo (pokud vím, ve většině demokratických ústav tomu tak je)“ (Havel 1992: 4). Ivan Mašek (ODA) argumentoval na 10. schůzi ČNR, že pro zajištění nezávislosti senátorů by mělo být jejich funkční období alespoň dvojnásobné ve srovnání s poslanci. „Bylo tomu tak za první republiky a připomínám, že v USA, kde mají volební období senátorů šestileté, je tomu tak ve vztahu $\mathrm{k}$ dvouletému období členů Sněmovny reprezentantů a jde tedy o trojnásobek délky mandátu“ (ČNR 1992f). Jinde jsou ale naopak stavěny zahraniční vzory jako fungující protiklady k nefunkčním institucím první republiky. Např́klad Václav Havel zmiňuje fungující druhé komory na regionální bázi v Německu a Rakousku (Havel 1992: 12-13).

V diskuzích se aktéři vymezovali také vůči soudobému stavu federálních institucí. Dělo se tak sice poměrně ojediněle, ale dělo. Např́iklad Jiří Bílý (HSDSMS) se ptal ohledně kvóra pro usnášeníschopnost Sněmovny takto „Máte pocit, že to, co máme zakotveno, a to, co je v našem ústavním systému, nefunguje? Mohli byste nějakým způsobem argumentovat? Každá změna má mít určitou př́činu. Řekněme si, kde vidíme problémy ve stávajícím ústavním pořádku“ (ČNR 1992b). Bílý takto odmítal znění prvorepublikové Ústavy a argumentoval funkčností současného ustanovení. Naopak Ivan Mašek označoval převzatou federální ústavu, ze které byly vypuštěny pouze ty nejproblémovější nedemokratické články, za „bolševickou“ (tamtéž), aby umocnil její odmítnutí.

\section{Závěr}

Tato studie si kladla za cíl ukázat, jak Ústava 1920 podporovala novou českou ústavu a dodávala jí legitimitu. Mou snahou bylo odhalit, jakou roli hrál politický systém první republiky a Ústava 1920 v argumentaci aktérů prúpravujících a schvalujících českou ústavu $\mathrm{v}$ roce 1992, a též v jakém kontextu se v textech první republika vyskytovala. Dále mě zajímalo, jaký obsah, resp. obsahy dávali 
politici konceptu politického systému první republiky a jakým způsobem ho/je používali.

Jak jsem na základě diskurzivní analýzy ukázala, doboví aktéři se soustředili mnohem více na zobrazení ústavního systému první republiky než na fungování politické praxe. Výjimku tvořil Senát, kde naopak převládaly zmínky o fungování v praxi. Domnívám se, že to pravděpodobně souvisí $s$ tím, že Senát byl zobrazován velmi kriticky a oproti dalším institucím i Ústavě 1920 jako celku byl spojován s neefektivností, zbytečností a nákladností. Je to vcelku pochopitelné, pokud vezmeme v úvahu odmítavý postoj převážné části opozice, Václava Havla, ale zpočátku i části koalice, vedle jeho samotného problematického fungování za první republiky. Prvorepublikový senát byl zobrazován jako nefunkční i aktéry z vládní koalice, ale s tím rozdílem, že jimi bylo zdůrazňováno, že návrh českého Senátu se vyvaroval starých chyb, resp. že se inspiroval starším návrhem prvorepublikového Senátu, který byl nakonec v roce 1920 odmítnut.

Je také zajímavé, že ačkoliv byl Senát zobrazován převážně negativně, přesto byl nakonec zř́zen. Naopak stálý výbor parlamentu byl zobrazován spíše kladně, parlamentní komise ho doporučovala, ale vládní komise ho odmítla s odůvodněním, že jeho pravomoci bude mít Senát a byl by z toho důvodu zbytečný.

Ústavní listina z roku 1920 a celkově prvorepublikový politický systém byly $\mathrm{u}$ většiny aktérů $\mathrm{z}$ celého politického spektra spojeny s pojmy demokracie, účinnosti, kontinuity, stability, suverenity. Nejčastěji však ve spojení s první republikou nacházíme pojmy jako tradice, tradiční, osvědčená tradice, dokonce i u jinak převážně velmi negativně zobrazovaného Senátu. Mưžeme tedy říci, že aktéri konstruovali obraz první republiky jako tradici, kterou bychom měli následovat a z níž bychom měli vycházet. Spojovali ji s demokracií a suverenitou. Vědomě tedy navazovali na jednu ze silných národních tradic (respektive ji reprodukovali), tedy tradici demokracie, s cílem zajištění podpory a uznání nové české ústavy.

Prvorepublikový politický systém a Ústava 1920 byly při debatách o ústavě tématem, které nešlo pominout a které se muselo v diskurzu objevit. Svědčí o tom to, že aktéŕi měli potřebu se k první republice určitým způsobem vztahovat, at' už kladně jako ke vzoru, nebo rezervovaně až skepticky s upozorněním, kde se od ní odklánějí anebo se vůči ní přímo vymezují. Někteří mluvčí ji také nezobrazovali správně a málokdy hovořili o problematických aspektech fungování politického systému první republiky (Pětka, Hrad...), čímž vytvářeli její mýtus. Nicméně vždy byla zmíněna jako určitý symbol, jehož význam byl mnohdy důležitější než skutečný obsah, protože mohl potvrzovat legitimitu mocenských vztahů a vyjadřovat identifikaci s danou politickou linií. Právě to, že si aktéŕi vybírali jen určité obrazy první republiky, a to převážně ty pozitivní, dokládá, že se snažili využít sílu symbolu první republiky. 
Z širšího pohledu výzkum potvrdil roli symbolů, tradic a mýtů v zajištění legitimity ústavy a z ní vycházejících politických institucí, a tím snad přispěl k porozumění tomu, jak náš ústavní text v roce 1992 vznikal. Je však nutno připustit, že historická tradice je pouze jedním z možných vlivů, které se do tvorby ústav promítají, a pro ucelenější porozumění bude třeba podrobně analyzovat také zájmy aktérů, roli hodnot a idejí a vliv zahraničních vzorů.

\section{Literatura a prameny}

Beneš, Vít (2008): „Diskurzivní analýza.“ In: Drulák, Petr (ed.), Jak ₹koumat politiku: kvalitativni metodologie v politologii a mezinárodnich vz̨azich. Praha: Portál, 92-124.

Birch, Sarah, Frances Millard, Marina Popescu a Kieran Williams (2002): Embodying Democracy: Electoral System Design in Post-Communist Europe. Basingstone: Palgrave Macmillan

Broklová, Eva (1992). Ceskoslovenská demokracie. Politický systém ČSR 1918-1938. Praha: SLON.

Broklová, Eva (1999): „Diskuze při př́pravě Ústavy České republiky.“ Acta Universitatis Carolinae. Iuridica 45(1-2): 65-71.

Cigánek, František (1992): Kronika demokratickébo parlamentu, 1989-1992. Praha: Cesty.

ČNR (1992a): Usnesení předsednictva ČNR z 2. 7. 1992. Společná česko-slovenská digitální parlamentni knihovna. Dostupné z http://www.psp.cz/eknih/1992cnr/predsedn/ usneseni/ue001.htm

ČNR (1992b): „Stenografický záznam jednání Komise předsednictva ČNR pro př́pravu Ústavy České republiky.“ Archiv Poslanecké snèmovny, fond ČNR - VII. volební období (1992), NAD 8, krabice 33 (doplněk k inventárnímu číslu 280)

ČNR (1992c): „Zásady Ústavy České republiky zpracované dne 18. 7. 1992.“ Archiv Poslanecké snèmovny, fond ČNR - VII. volební období (1992), NAD 8, krabice 33 (doplněk k inventárnímu číslu 280)

ČNR (1992d): „Usnesení č. 1 Komise předsednictva ČNR pro př́pravu Ústavy České republiky." Archiv Poslanecké snèmovny, fond ČNR - VII. volební období (1992), NAD 8, krabice 33 (doplněk k inventárnímu číslu 280)

ČNR (1992e). „Odůvodnění návrhu Ústavy České republiky podaného poslanci Levého bloku v České národní radě." Arcbiv Poslanecké snèmovny, fond ČNR - VII. volební období (1992), NAD 8, krabice 33 (doplněk k inventárnímu číslu 280)

ČNR (1992f): „10. schůze ČNR 16. 12. 1992.“ Společná česko-slovenská digitální parlamentni knihovna. Dostupné z http://www.psp.cz/eknih/1992cnr/stenprot/010schuz/s010001 .htm

Dogan, Mattei (1992): „Conceptions of legitimacy.“ In: Hawkesworth, Mary a Maurice Kogan (eds.), Encyclopedia of government and politics. Volume I. London, New York: Routledge, 116-125.

Drahoš, Jiří (2013): „Úvodní projev předsedy Akademie věd České republiky.“ In: Gerloch, Aleš a Jan Kysela (eds.), 20 let Ústavy Ceské republiky: oblédnutí apeét a pobled vpréed. Plzeň: Vydavatelství a nakladatelství Aleš Čeněk, 18-21.

Elgie, Robert a Jan Zielonka (2001): „Constitutions and Constitution-Building: A Comparative Perspective.“ In: Zielonka, Jan (ed.), Democratic Consolidation in Eastern 
Europe. Volume I. Institutional Engineering. Oxford, New York: Oxford University Press, 165-185.

Elster, Jon (1995): „Forces and Mechanisms in the Constitution-Making Process.“ Duke Law Journal 45(2), 364-396.

Elster, Jon, Claus Offe, Ulrich K. Preuss, et al. (1998): Institutional Design in Post-communist Societes. Rebuilding the Ship at Sea. Cambridge: Cambridge University Press.

Fallon, Richard H., Jr. (2005): „Legitimacy and the Constitution.“ Harvard Law Review 118(6), 1789-1853.

Filip, Jan (1999): „Volební inženýrství v letech 1990 až 1992. Studie konkrétního prŕípadu. "In: Klíma, Michal (ed.), Možnosti úpravy či reformy volebníbo systému v ČR. Praha: VŠE, 79-94.

Filip, Jan (2002): „Zapomenuté inspirace a aspirace Ústavy ČR (K 10. výročí přijetí Ústavy ČR). “ Casopis pro právni védu a praxi 10(4), 295-302.

Filip, Jan (2003): „Deset let Ústavy ĆR: východiska, stav, perspektivy.“ In: Kysela, Jan (ed.): Deset let Ústavy Ceské republiky: východiska, stav, perspektivy. Praha: Eurolex Bohemia, 25-35.

Flegl, Vladimír (1989). Dokumenty k vývoji českého ústavního práva. Praha: Ústav státní správy

Gerloch, Aleš (1999): Dělba moci v ústavě Československé republiky (1920) a v Ústavě České republiky (komparace). Acta Universitatis Carolinae. Iuridica. 1999, 167-179.

Gerloch, Aleš, Vladimír Zoubek a Jiří Hřebejk (2013): Ústavni systém České republikey. Plzeň: Vydavatelství a nakladatelství Aleš Čeněk.

Gill, Rosalind (2000): „Discourse Analysis.“ In: Bauer, Martin a George Gaskell (eds.), Qualitative Researching with Text, Image, and Sound. London: SAGE, 172-190.

Havel, Václav (1992): „Několik poznámek na téma české Ústavy.“ In: Chrastilová, Brigita a Petr Mikeš (eds.) (2003): Prezident republiky Václav Havel a jeho vliv na reskoslovenský a český právni rád. Praha: ASPI Publishung, 371-389.

Hendrych, Dušan, et al. (1997): Ústava České republiky: komentár. 1. vyd. Praha: C.H. Beck. Holý, Ladislav (2010): Maly český člověk a skvěly český národ. Vyd. 2. Praha: Sociologické nakladatelství (Slon).

Charvát, Jakub (2013): Politika volebnich reforem v ČR po roce 1989. Praha: Grada.

Ifversen, Jan (2003): „Text, Discourse, Concept: Approaches to Textual Analysis.“ Kontur 7: 60-69

Jičínský, Zdeněk (2003): „K legitimitě parlamentu samostatné ČR.“ In: Kysela, Jan (ed.): Deset let Ústavy Ceské republiky: východiska, stav, perspektivy. Praha: Eurolex Bohemia, 72-77. Jirásková, Věra (1999): Diskuque prù př́pravě Ústavy Ceské republiky. Acta Universitatis Carolinae. Iuridica, 193-199.

Jirásková, Věra (2010): „„,Ústavní vzory“ - jejich přijetí a legitimita.“ In: Mlsna, Petr (ed.), Ústava ČR - vžnik, vývoj a perspektivy. Praha: Leges, 174-189.

Kopecký, Petr (2001): Parliaments in the Czech and Slovak Republics. Party competition and parliamentary institutionalization. Aldershot: Ashgate.

Kopeček, Lubomír (2010): Éra nevinnosti. Ceská politika 1989-1997. Brno: Barrister \& Principal.

Kysela, Jan (2004): Dvoukomorové systémy. Teorie, historie a srovnáni dvoukomorových parlamentu. Praha: Eurolex Bohemia. 
Linz, Juan (1988): „Legitimacy of Democracy and Socioeconomic System.“ In: Dogan, Mattei (ed.), Comparing Pluralist Democracies: Strains on Legitimacy. Boulder: Westview Press, 65-113.

Lipset, Seymour Martin (1959): Political man, The Social Basis of Politcs. New York: Doubleday.

Mlsna, Petr (2010): „Filozofické a ideové zdroje Ústavy ČR.“ In: Mlsna, Petr (ed.), Ústava ĆR - vznike, vývoj a perspektivy. Praha: Leges, 15-44.

Němeček, Tomáš (2010): Vojtěch Cepl-Zivot prárníka ve 20. století. Praha: Leges.

Offe, Claus (1996): „Designing Institutions in East European Transitions.“ In: Goodin, Robert E. (ed.), The Theory of Institutional Design. Cambridge: Cambridge University Press, 199-226.

Renwick, Alan (2010): The Politics of Electoral Reform. Changing the Rules of Democracy. Cambridge: Cambridge University Press.

Stein, Eric (2000): Czecho-Slovakia: Etnic Conflict, Constitutional Fissure and Negotiated Breakup. Ann Arbor: University of Michigan Press.

Suchánek, Radovan (1999): Diskuzue prü prípravě Ústavy Céské republiky. Acta Universitatis Carolinae. Iuridica, 65-71.

Suchánek, Radovan a Vera Jirásková, et al. (2009): Ústava Ceské republiky v praxi : 15 let platnosti základního zákona. Praha: Leges.

Suk, Jiří (2003): Labyrintem revoluce: aketérí, zápletky a križovatky jedné politické krize: od listopadu 1989 do cervna 1990. Praha: Prostor.

Syllová, Jindřiška (2003): „Ústavní charakteristika Parlamentu ČR a její naplňování.“ In: Kysela, Jan (ed.), Deset let Ústavy Ceské republiky: východiska, stav, perspektivy. Praha: Eurolex Bohemia, 259-263.

Syrjämäki, Sami (2013): What is conceptual history? Concepta. International Research School in Conceptual History and Political Thought, on-line (http://www.conceptanet.org/conceptual_history), [ověřeno k 5. 7. 2016].

Tonkiss, Fran (2004): „Analysing discourse.“ In: Seale, Clive (ed.), Researching society and culture. London: Sage, 245-260.

Usnesení předsednictva ČNR z 2. 7. 1992. Společná česko-slovenská digitální parlamentní knihovna. Dostupné z: http://www.psp.cz/eknih/1992cnr/predsedn/usneseni/ue001. htm, [ověřeno k 5. 7. 2016].

Ústava Ceské republiky ze 16. prosince 1992, ústavní zákon č. 1/1993 Sb.

Vodička, Karel (2000): „Interdependence mezi politickými procesy a ústavním právem.“ In: Pavlíček, Václav (ed.), Transformace ústavnich systému zemi stredni a východni Evropy. Sbornik príspèvkư a statí z. konference. Praha 15.-16. října 1999. II. část, Vodnár̆, Praha, 116-124.

Vodička, Karel a Ladislav Cabada (2003): Politický systém České republiky: Historie a současnost. Praha. Portál.

Wintr, Jan (2013): „Dvacet let české parlamentní kultury.“ In: Gerloch, Aleš a Jan Kysela (eds.), 20 let Ústavy České republiky: oblédnuti apèt a pobled vpréd. Plzeň: Vydavatelství a nakladatelství Aleš Čeněk, 256-264. 


\section{Image of the first Czechoslovak Republic in the debate about the Czech Constitution}

\section{SUMMARY}

This paper focuses on the image of the political system of the first Czechoslovak Republic, or its constitution in a political discourse when addressing the Constitution of the Czech Republic. I pursue three fundamental research questions in the paper: firstly, what image of the First Republic was created in the debates on the constitution? Secondly, in what context the First Republic appeared in the discussions and argumentations, and ultimately, what role such an image played in the discourse.

References to the inspiration by the First Republic may be found in a variety of places, for instance in the preamble to the constitution, in a commentary to the constitution, framed by the very authors of the constitution (Hendrych et al. 1997); furthermore, it is frequently cited by Czech constitutional lawyers as well as foreign authors capturing the emergence of constitutional systems (eg. Filip 2002; Jirásková 2010; Mlsna 2010; Kopecký 2001; Elster 1995; Elster, Offe, Preuss et al. 1998).

The paper draws on the thesis that the political and constitutional system of the First Czechoslovak Republic, as a symbol of democratic tradition, was used to support the legitimacy of the new Czech constitution. The legitimacy of political institutions is perceived here in accordance with its modern definition based on faith, confidence, or conviction. For example, according to Dogan, institutions are legitimate when people deem them appropriate and morally correct (Dogan: 116). Fallon even argues that the social acceptance of the constitution bears more importance for its legitimacy than the way in which it is created or ratified (Fallon 2005: 1787).

The Czech state builds its legitimacy on the First Czechoslovak Republic, which is very positively accepted among politicians and ordinary citizens as well. Czech democratic tradition is accentuated as an important part of the political culture (Holý 2010: 20) and this can be well documented; for instance, both Czech and foreign analysts often point to Czechoslovakia as being the only democratic country in Central Europe during the interwar period. Accordingly, it is necessary to examine how the tradition is being reproduced in social practice and whose interests it embodies and promotes, because although we seemingly invoke such a tradition in order to render sense to the past, we always recall it either to refer to the present or to future goals. Tradition is thus recalled in order to legitimize or replace the current status quo and to mobilize people (ibid.: 139).

Moreover, I draw on the assumption that states enhance their symbolic power by referring to their past, which is viewed as famous, grand, good. Therefore, the First Republic also functions as a symbol, and symbols can move us. They can be used to convince us of the benefits of a political program, to confirm the legitimacy of power relations and to express identification with a given political line. Symbols, myths and traditions facilitate people's identities as members of a nation and the moulding of national consciousness (ibid.: 10-11). 
The paper is based on an analysis of records from the parliamentary debates on the constitution during the period from June to December 1992 (preparation of the constitution) and the text by Václav Havel "A few notes on the subject of the Czech Constitution” (Několik poznámek na téma české Ústavy) where Havel outlined his vision of a new constitution for the committees preparing the Czech Constitution. Politicians with real power to influence the form of the constitutional system, mainly the members of both committees for the preparation of the constitution, were regarded as the main actors as well as constitutional experts and political figures with large informal influence such as Václav Havel. Applying a discourse analysis, I examine the role played by the political system of the First Republic and the Constitution of 1920 in the argumentation of actors preparing and approving the Czech Constitution in 1992 and the context in which the First Republic occurred in the texts. In other words, I attempt to capture what content, or what contents the Czech politicians attributed to the concept of the political system of the First Republic and I seek associations bound to the key concept of the First Republic in the discourse. The ways in which we name things and contextualize them determine our perception of the world (Holý 2010: 215). We employ concepts and symbols as tools through which we interpret and create the world we live in. I primarily conduct an analysis of the vocabulary, while paying attention to the key words, phrases or themes and to finding associations between them. Therefore, I do not concentrate on the structure of a discourse in my analysis, but rather on its content.

Working on the basis of a discourse analysis has revealed that actors at the time focused much more intensely on the portrayal of the constitutional system of the First Republic rather than on the functioning of political practice, with the exception of the Senate, where - on the contrary - remarks related to its functioning in practice prevailed. I assume this is most likely due to the fact that the Senate was shown very critically and, unlike other institutions and the Constitution of 1920 as a whole, it was associated with inefficiency, pointlessness and high costs. It is quite logical when considering a negative attitude of most of the opposition, Václav Havel, and initially also part of the coalition vis-à-vis the Senate and its problematic functioning under the First Republic. The Senate of the First Republic was portrayed as dysfunctional by actors from the government coalition as well; however, they also emphasized that the draft of the new Czech Senate avoided the past mistakes, or was inspired by an older proposal of the Senate under the First Republic, which was finally rejected in 1920.

It is also quite interesting that although the Senate was largely portrayed negatively, it was indeed eventually established. Conversely, a standing committee of the parliament was portrayed more positively, a parliamentary committee recommended it, yet a government committee rejected it on the grounds that its powers would be vested in the Senate and it would thus be redundant.

For the majority of actors across the political spectrum, the Constitution of 1920 and the political system of the First Republic as such were associated with the concepts of democracy, efficiency, continuity, stability, and sovereignty. Most often, however, in connection with the First Republic we come across terms such as tradition, traditional, proven tradition, even the otherwise mostly very negatively portrayed Senate. We may thus claim that actors constructed an image of the First Republic as a tradition we should follow and we should build on. They associated it with democracy and sovereignty. Thus, they consciously pursued or reproduced one of the strong national traditions, a tradition 
of democracy, in order to ensure the endorsement and recognition of the new Czech Constitution.

When debating the constitution, the political system of the First Republic and the Constitution of 1920 represented an issue that could not be ignored and which had to emerge in the discourse. This testifies to the fact that the actors felt compelled to relate to the First Republic in some way, whether positively as a model, or to point out where they diverged from it or were directly opposed to it. Some speakers did not always portray it accurately and rarely spoke about the problematic aspects of the functioning of the political system of the First Republic (the Five, the Castle ...), thus creating its myth. However, it was always alluded to as a symbol whose meaning was often more important than its actual content, as it could confirm the legitimacy of power relationships and express identification with a given political line. The fact that the actors chose only certain images of the First Republic, mostly the positive ones, illustrates that they sought to use the power of the symbol of the First Republic. 